Association for Information Systems AIS Electronic Library (AISeL)

AMCIS 2002 Proceedings

Americas Conference on Information Systems

(AMCIS)

December 2002

\title{
E-COMMERCE ADOPTION IN DEVELOPING COUNTRIES
}

Mike Raisinghani

University of Dallas

Robert Vinaja

University of Dallas

Adel Aladwani

University of Dallas

Follow this and additional works at: http://aisel.aisnet.org/amcis2002

\section{Recommended Citation}

Raisinghani, Mike; Vinaja, Robert; and Aladwani, Adel, "E-COMMERCE ADOPTION IN DEVELOPING COUNTRIES" (2002). AMCIS 2002 Proceedings. 104.

http://aisel.aisnet.org/amcis2002/104

This material is brought to you by the Americas Conference on Information Systems (AMCIS) at AIS Electronic Library (AISeL). It has been accepted for inclusion in AMCIS 2002 Proceedings by an authorized administrator of AIS Electronic Library (AISeL). For more information, please contact elibrary@aisnet.org. 


\title{
E-COMMERCE ADOPTION IN DEVELOPING COUNTRIES
}

\author{
Mike Raisinghani, Robert Vinaja, and Adel M. Aladwani \\ Graduate School of Management \\ University of Dallas
}

\section{Introduction}

Electronic Commerce (e-commerce) has many benefits to all the countries that participate in its growing infrastructure. It is especially important for developing countries (DC) since various products and services are available to third world countries that have never been available before. Another benefit is that the e-commerce is available 24 hours a day, 7 days a week. E-commerce allows for facilities to provide public services, social services, such as healthcare, education, distribution of social government services at reduced cost and improved quality that was not available before. Moreover, information that took maybe weeks, months or years is now available instantaneously. Although it has not yet been proven that the Internet represents a full benefit to these developing countries, the technology now available allows for these countries to have something to look forward to. Cost may still be detrimental in these developing countries but with the constant innovation of software, hardware and networking equipment, soon the cost may be affordable for these countries to enable them to purchase the requisite technology and have access to e-commerce in their country.

The people who are using the internet for e-commerce in the third world nations are being greatly benefited because now they can buy things that could only be found in developed cities, for example in Milan, London, New York, Berlin, Tokyo, Sydney or any other city that may geographically be far away from these developing countries. This has helped to close the gap between the countries that have some products/services in their own cities and others that do not have such products/services in their cities. The basic purpose of e-commerce is to be able to reach and transact business with people that do not live close to the physical location of the product or service and who would otherwise have a hard time acquiring these products/services.

The benefits for developing countries range from social to economic. Some of the benefits include: improvement of international coordination, an open economy promoting competition and diffusion of key technologies, efficient social and infrastructure services, a competitive telecommunications sector, and increased buyer productivity Some of the barriers include disproportionate penetration of the telephone in the urban as opposed to rural areas (for example, in Nepal, 80 percent of the population is rural and has merely 6 telephone lines available per 10,000 inhabitants), limited and/or expensive access to the Internet, lack of intraregional infrastructure, lack of tradition of remote shopping/selling, lack of trust in product/service quality, lack of customer protection laws, and lower transactional capability $[21,22,31)$.

\section{Background}

Society and consumers alike have only begun to enjoy the benefits of e-commerce. Since new developments are made on a continuous basis it will eventually affect every individual. Some of the benefits enjoyed by society and consumers, for example are ease of transaction, comparability of products, quick delivery and the ability to make any type of transaction at any given time of the day. Electronic commerce facilitates delivery of public services, such as healthcare, education, and distribution of government social services at a reduced cost, improving the quality of care and living in these communities. For example, health care services can reach patients in rural areas [32].

E-commerce (based on the Internet) also facilitates the people to be better educated and better informed of happenings around the world. For example, the opportunities for people to participate in online education/training and earn a college degree/certificate. In addition, many developing-country universities are focusing on curricula that might contribute more directly to economic growth, thus making the network connections for administrators, professors, and students increasingly important [7]. 
The communications and information delivery capability of the Internet serves all sectors of society. The areas of education, health, social policy, commerce and trade, government, agriculture, communications, and science and technology all benefit from Internet access to information.[26]). Furthermore, as it has been demonstrated in a number of countries recently, the link between the free flow of information and movement toward democratization cannot be downplayed. Access to information affects political democratization efforts at not only the national but also the global level [35].

\section{ITU}

Various organizations such as the ITU (International Telecommunication Union), the GII (Global Information Infrastructure), the NII (National Information Infrastructure), the OECD (Organization for Economic Cooperation and Development), and the EU (European Union), are striving to develop standards and policies to promote business on the Internet 35 During March of 1998, The World Trade Center in Geneva and the World Internet Service Key in conjunction with the International Telecommunications Union launched a project to expand electronic commerce in developing countries [9]. The purpose of the "Electronic Commerce for Developing Countries" (EC-DC) project is to help in the "construction" of e-commerce infrastructure and implementation of e-commerce solutions.

The International Telecommunication Union's web project on "Electronic Commerce for Developing Countries" is being deployed in more than 100 countries. It is a massive project under which participating countries can benefit from state-of-the-art security, trust and services for e-business transactions under affordable conditions by pooling and using available resources. The ecommerce in the Developing Countries (EC-DC) project will assist the ITU in expanding it, using the World Trade Center network and its global resources of more than 300 centers in more than 100 countries. The EC-DC project addresses some of the challenges and opportunities faced by developing countries in the application of new technologies. The ITU is assisting developing countries to acquire and benefit from electronic commerce technologies through a program focused on concrete deliverables.

As a result of this project the following sectors will automatically benefit form it:

- Economic Development: "micro and small businesses can begin to trade at internationally acceptable price levels and bypass the system of exploitation of their products for minimal return [19]." EC maximizes a company's reach into all available markets. The companies are able to trade at internationally acceptable price levels and among and across many borders. Benefits in the tourism, travel, arts, sale of locally produced goods, service industry and the banking sector are greatly seen because of the ability of EC to reduce the cost of processing orders and payments in the global marketplace. This is turn contributes to an "economic upliftment" [11].

- Infrastructure: EC will stimulate demand for Internet connection infrastructure and encourage the creation of commerce [19]). As a result, polices in the banking and information and communication technology sectors will bring together the public and private "communities" to support infrastructure development. In order to provide immediate benefits and increase the chances of sustainability of the project, the initial focus has been on businesses that already have an export market. EC will broaden their markets, increase their competitiveness by providing a low-cost access to a worldwide customer base. It will also enable the transfer of electronic commerce technologies through the development of human resources necessary for providing electronic commerce services and maintaining the infrastructure [11].

- Regional and multi-national cooperation: The improvements in the infrastructures will facilitate communication between business and consumers [19] EC "increases the collaboration between the various sectors of government, banking, business and information technology of the country" [11]. One of the social benefits that e-commerce provides to developing countries is the "sharing of ideas and the collaboration among different cultures across borders". The ability to share different methods of doing basic or complicated tasks among different people is very appealing to the social growth of the DC's. The "local and international organizations that work for the people of DC's" are able to perform their social service to more people". As organizations develop and grow so do the advantages for citizens and government. More jobs are created as demands for products rise due to the large exposure precipitated by e-commerce.

Next we provide some case examples of countries, which have benefited from electronic commerce. 


\section{Thailand and India}

In Thailand e-commerce is expected to grow fivefold this year, according to the American Enterprise Institute, Washington, D.C. In India, it's expected to grow by $\$ 15$ billion within two years (http://seattlep-i.nwsource.com/business/ecom26.shtml). The benefits of information and communication technology applications can be broadly categorized as decision support to public administrators, improving services to citizens, and empowering citizens to access information and knowledge [5]. Nair and Prasad's [17] study shows that in a democratic country like India, where $40 \%$ of the people are still living below the poverty line, mobilization of huge investment required for the implementation and maintenance of e-governance project is quite difficult. However, in spite of financial constraints, Kerala, one of the federal states of India, has made significant achievements in egovernance. The Internet is "absolutely critical" to World2Market.com, which launched in September 2001. This site displays and sells on its site handcrafted goods from developing countries, promising the artisans a living wage delivered without delay. According to its co-founder Michelle Long, "Buyers get beautiful, unique, hand-crafted goods, but more than that, they get the great story" of how their purchase preserves native arts, lets villagers stay at home rather than migrating to city factories, and reduces poverty.

\section{Mexico}

For Mexico as well as other Latin American countries, tourism is of great economical impact, therefore a number of different web pages that are dedicated to support, promote and sell to the national and international tourism. For any developing country electronic commerce is a great way to enter into foreign markets and compete in the rapidly growing global economy. In the case of Mexico, the recent implementation of NAFTA has led them to acquire or copy some of our technological advancements. This includes some of our electronic commerce applications. According to John F. Smith, the Chief Executive Officer and President of General Motors (GM) Corporation, global communication links also make transportation faster and less expensive than anybody would have imagined just a few years ago, which makes it much simpler to conduct business The benefits that these bring to Mexico are much the same as it does to other countries, but since Mexico is a developing country it provides them even greater benefits. Electronic Commerce reduces inventory and overhead. In addition, you are able to customize the products and services to better fit the needs of consumers, suppliers, and employees. Mexico is also enjoying the access to services and products manufactured in foreign countries that were not accessible to them before. Many Mexicans are now earning college credits from the comfort of their own homes from universities who offer on-line courses. Countries like Mexico are coming along quickly and taking advantage of the rewards of e-business.

\section{Panama}

Panama has implemented many initiatives for EC [18]. Panama's tourism can benefit from this by putting information of the best places to visit in their country over the web.

Travel agencies can get their sites on the web and could be hit by virtually any body in the world wanting to visit the country. There will be plenty of benefits for organizations, such as saving on the cost of brochures, advertising in international newspapers or magazines, and on methods of payments that they have to do through their bank (Tradeport, 2000).

\section{Malaysia}

With the rapid growth in technology, developing countries such as Malaysia can take part in the global e-commerce explosion. Malaysia's e-commerce boom is not just a simple phenomenon that has occurred by simply connecting to the Internet or teaming up with world leaders in IT (Information Technology). Malaysia's e-commerce expansion can be partially credited to the growth in PC purchase and use in that nation, the actual hardware and networking technology that form the backbone of e-commerce. The growth of PC's in the nation provides another source of $\mathrm{C} 2 \mathrm{~B}$ (consumer-to-business) and C2C (consumer-to-consumer) ecommerce.

The new e-commerce markets are giving Malaysia more opportunities from within the country and not just from foreign nations. The growth of PC ownership is about $25 \%$ a year. The significance of PC growth, in relation to e-commerce, is that Malaysian citizens will also have access to the global markets to be able to buy products and services at a much lower cost. So, not only will Malaysia's suppliers be growing and expanding the economy but also the citizens will be able to enjoy this growth in the 
economy. When the citizens of any nation can buy a product at a lower cost, that gives the citizens more buying power which in turn gives them more money to save or possibly invest within their own nation. So, E-Commerce is more than just Malaysia's ability to supply global, potential buyers with products. It is an overall impact on Malaysia's economy, thanks to the various implementations of e-commerce.

\section{Africa}

Although the African continent has the least developed telecommunication network in the world [6], yet e-commerce has provided some benefits towards consumers for a developing country like Africa. Without the Internet access many of Africa's citizens would have a very hard time finding products/services that are not available in their small town stores. Even if they were to find the items that they were looking for they would have to travel very long distances to get them.

\section{Arab Countries}

- The Internet was introduced to the region in early $1990 \mathrm{~s}$.

- Good telecommunications infrastructure in most countries.

- $\quad$ Estimated number of Internet users $\sim 3$ million.

- $\quad$ Estimated number of Internet hosts $\sim 66000$.

- Some initiatives for e-governments including Kuwait, UAE, Saudi Arabia.

- $\quad$ Expectations for e-commerce growth is positive.

\section{Future Trends}

Rapid expansion of the Internet holds substantial promise for developing nations, which can benefit greatly from the Internet's communication and information delivery capabilities to help meet these needs [35]. Developing countries have much to gain from that revolution in communication and information access. E-commerce will give developing countries an increase in jobs, wealth and health. With the creation of new jobs the economy improves. EC will also provide help, services and jobs, the reduction of unemployment and the growth of GDP, this will also result in an improvement of the living conditions of the population [30]. EC will have potential economic advantages in travel, tourism, sale of locally produced goods, and the banking industry because it lowers the cost of processing orders and payments and is accessible to the global market. E-commerce allows small business to sell their product from anywhere in the world. At the long run, producers will be able to provide better customer service and will enable people in Third World Countries and rural areas to enjoy products and services that otherwise are not available to them [32].

\section{Conclusion}

Governments of the developing countries have finally realized that it is time to increase wealth in their communities and for their people and are open to the ideas of e-commerce and the opportunities that are tide in to it."[4]. It is essential, that developing countries increase their access to the Internet and to e-commerce for their ability to perform in the constantly growing global market of the digital economy. The expansion of electronic commerce to developing countries will automatically enable their overall economy. The acceptance of e-commerce all over the world is giving everyone the opportunities for advancement in all levels of society. The most important goal is giving developing countries the chance for better living conditions, increase in job opportunities, availability of services, better education and greater economic wealth. Future work may focus on empirically validating the proposed conceptual model using data provided by potential e-Commerce adopters from one or more developing countries.

\section{References}

[1] A. M. Aladwani, Attitudes toward and acceptance of Internet in Kuwait, Proceedings of the 1st World Conference of GITM, Memphis, TN, 2000. 
[2] A. M. Aladwani, End-user computing usage by Kuwaiti managers: The role of individual characteristics, Journal of the Gulf and Arabian Peninsula Studies 27 (100), 2001, pp. 17-37.

[3] A. M. Aladwani, Online banking: A field study of drivers, development challenges, and expectations, International Journal of Information Management 21 (3), 2001, pp. 213-225.

[4] Asia Society's Asia Business. "A Resource for Information On Asian Economies” http://www.asiabusinesstoday.org/pp. 2-3.

[5] Bhatnagar, Subhash, Social Implications of Information and Communication Technology in Developing Countries: Lessons from Asian Success Stories, The Electronic Journal on Information Systems in Developing Countries, Volume 1, January, 2000 http://www.ejisdc.org

[6] Coeur de Roy, Olivier, "The African challenge: Internet, networking and connectivity activities in a developing environment." Third World Quarterly, December, 18(5), 1997 pp. 883-898.

[7] DPI , "Electronic Commerce Offer Great Potential for Developing Countries"; DPI Release, November 9, 1998 http:// www. partners.uctad.cn/english/R2/tad9803e.htm

[7] M. Fishbein, I. Ajzen, Belief, Attitude, Intention and Behavior: An Introduction to Theory and Research, Addison-Wesley Publishing Company, Reading, MA, 1975.

[8] D. Gefen, E-commerce: The role of familiarity and trust, Omega 28, 2000, pp. 725-737.

[9] Goh, Kelvin, ITU teams up to push e-biz in developing world, IDG News Service/Boston Bureau, 29 September, 2001 pp.13:25.

[10]Hillebrand, Mary, , “Asian E-Commerce Set to Go”, E-Commerce Times, May 6.1999

[11] International Telecommunications Union , "Electronic Commerce for Developing Countries." available at http://www.itu.int/ECDC/. March 30. 2001

[12] International Telecommunications Union, "Report on the e-commerce survey conducted in the framework of World Telecommunication Day 1999”, 1999 http://www.itu.int/newsarchive/wtd/1999/report.html, p.11.

[13] E. Karahanna, D. W. Straub, The psychological origins of perceived usefulness and ease-of-use, Information \& Management 35 (4), 1999, pp. 237-250.

[14]E. Karahanna, D. W. Straub, N. L. Chervany, Information technology adoption across time: A cross-sectional comparison of pre-adoption and post-adoption beliefs, MIS Quarterly 23 (2), 1999, pp. 183-213.

[15]Z. Liao, M. T. Cheung, Internet-based e-shopping and consumer attitudes: An empirical study, Information \& Management 38 (6), 2001, pp. 299-306.

[16] Markus, Lynne M., and Soh, Christina, "Structural Influences on Global e-commerce Activity," journal of Global Information Management, 10(1), 2002 pp. 5-12

[17] Nair, K.G.K. and Prasad, P. N., "Development through Information Technology in Developing Countries: Experiences from an Indian State", The Electronic Journal on Information Systems in Developing Countries, Volume 8, March, 2002 http://www.ejisdc.org

[18] National Law Center for Inter-American Free Trade, , "Panama: Proposed Regulation of Electronic Commerce", 2000 http://www.natlaw.com/ecommerce/docs/stpnec1.htm

[19] Ochiengs, Christine \& Amey, Chris F, "Electronic Commerce for Developing Countries (EC-DC): A Special ITU Development Initiative", 1998 International Telecommunication Union, Retrieved Online. www.mamma.com on 29 March 2001.

[20]Palvia, P., Palvia, S., Roche E. (Eds.), "Global Information technology and E-Commerce," Marietta, GA: Ivy League Publishing. 2002

[21] Petrazzini, Ben and Kibati, Mugo, "The Internet in Developing Countries," Communications of the ACM, 42(6), 1999 pp. 31-36.

[22] Plant, Robert, "E-Commerce: Formulation of Strategy." Upper Saddle River, NJ: Prentice-Hall. 2000

[23]Richman, Dan, "Advocates hope for fair trade e-commerce:Developing countries' restrictions a concern", Seattle PostIntelligencer, November 26, 1999 http://seattlepi.nwsource.com/business/ecom26.shtml

[24]E. M. Rogers, Diffusion of Innovations, Third Edition ed., The Free Press, New York, 1983.

[25] G. Rose, D. W. Straub, Predicting general IT use: Applying TAM to the Arabic world, Journal of Global Information Management 6 (3), 1998, pp. 39-46.

[26] Sadwosky, George, "The Internet Society in Developing Countries"; Nov/Dec 1996 http://www.isoc.org/oti/articles/196/sadwosky.html

[27]D. W. Straub, M. Keil, W. H. Brenner, Testing the technology acceptance model across cultures: A three country study, Information \& Management 33 (1), 1997, pp. 1-11.

[28] M. Tan, T. S. H. Teo, Factors influencing the adoption of Internet banking, Journal of Association for Information Systems 1 (Article 5), 2000, pp. 1-42. 
[29] S. Taylor, P. A. Todd, Understanding information technology usage: A test of competing models, Information Systems Research 6 (2), 1995, pp. 144-176.

[30] The African Development Forum, "Electronic Commerce in Africa", Section 5.5, 1999 pp. 26-48.

[31] Travica, Bob, "Diffusion of Electronic Commerce in Developing Countries: The Case of Costa Rica", Journal of Information Technology Cases and Applications, 2002 pp. 4-24.

[32] Turban, Efraim and Lee, Jae, and King, David and Chung, H. Michael, "Electronic Commerce 2002: A Managerial Perspective. New Jersey". Prentice-Hall, Inc. 2002

[33] U. S. Department of Commerce - National Trade Data Bank, Panama Marketing U. S. Products And Services, September 3, $1999 \mathrm{http}: / /$ www.tradeport.org/ts/countries/panama/market.html

[34] V. Venkatesh, Creation of favorable user perceptions: Exploring the role of intrinsic motivation, MIS Quarterly 23 (2), 1999 , pp. 239-260.

[35] Worldbank, "Developing Countries Could See Fastest Growth in Over a Decade But Are Hurt by Trade Barriers in Rich Nations"; New Release No: 2001/126/S, December 5, 2000. http://www.wbln0018.workdbank.org/news/pressrelease.ns and http://wbln0018.worldbank.org/news/pressrelease.nsf/673fa6c5a2d50a67852565e2006 